\title{
To our reviewers ... Muchas gracias!
}

Latino Studies (2014) 12, 168. doi:10.1057/lst.2014.17

Our reviewers make an invaluable contribution toward ensuring the ongoing high quality and warm reception of our journal. Their rigorous, punctual and balanced reviews of the latest publications in the field have assisted enormously in ensuring that we continue to be the foremost venue for scholarly conversation in the field of Latino Studies today.

As we begin our journal's twelfth volume, we want to take this opportunity to express our appreciation to the reviewers of the articles we both published and considered for publication in Volume 11. We truly value your expertise and continued support of Latino Studies.

Muchas gracias to ...

Elivia Arriola

Lisa Bedolla

Cynthia Bejaran

Judith Boruchoff

David Brotherton

Alejandra Castañeda

Elena Cepeda

Alexandra Delano

Grace Delgado

Jorge Duany

Jonathan Fox

Luin Goldring

John González

Ramón Grosfuguel

Laura Halperin

David Manuel Hernández

Tanya Hernández
Kevin Johnson

Jacqueline Lazú

Alejandro Lugo

Myra Mendible

Kirsten Nigro

Edna Ochoa

Yajaira M. Padilla

Richard Pérez

Gaspar Rivera-Salgado

Gilberto Rosas

Ron Schmidt

Gary Segura

Blanca Silvestrini

Christina Sisk

Miren Uriarte

Anahí Viladrich

Rodolfo Zamora 